\title{
KETRIADITISAN KONTEKS PRAGMATIK TUTURAN TIDAK SANTUN: PERSPEKTIF KULTUR SPESIFIK
}

The Triadicity of Pragmatic Contexts on Impolite Utterances:

A Culture-Specific Perspective

\author{
R. Kunjana Rahardi \\ Sanata Dharma University \\ rahardi.kunjana@gmail.com
}

Article received on 21 December 2019 — Final revised on 15 April 2020 - Approved on 08 May 2020

doi: https://doi.org/10.26499/rnh/v9i1.2340

\begin{abstract}
Abstrak
Tujuan penelitian ini adalah untuk mendeskripsikan tipe-tipe ketriaditisan konteks pragmatik dalam bahasa Indonesia dengan perspektif kultur spesifik. Data penelitian berupa tuturan-tuturan natural manusia dalam domain kultur spesifik yang secara implisit mengandung triadisitas konteks pragmatik tersebut. Data dikumpulkan dengan menerapkan metode simak, baik simak libat cakap maupun simak bebas libat cakap. Teknik pengumpulan data yang diterapkan adalah teknik catat dan teknik rekam. Selain teknik-teknik tersebut, diterapkan pula teknik wawancara, baik yang sifatnya semuka maupun tidak semuka. Tahap pengumpulan data dipandang selesai ketika data benar-benar telah siap untuk dianalisis. Selanjutnya, analisis data dilakukan dengan menerapkan metode padan, khususnya padan yang bersifat ekstralingual. Metode tersebut selaras dengan metode analisis kontekstual dalam pragmatik. Hasil penelitian menunjukkan bahwa terdapat 10 jenis ketriaditisan konteks pragmatik dalam bahasa Indonesia dalam perspektif kultur spesifik. Kesepuluh jenis tersebut adalah ketriaditisan konteks pragmatik dalam tuturan yang mengandung makna: (1) kepura-puraan, (2) asosiasi, (3) tabu, (4) ejekan, (5) kesombongan, (6) pleonasme, (7) lelucon, (8) hinaan, (9) godaan, (10) interjeksi. Temuan penelitian ini diyakini dapat memberikan kontribusi signifikan bagi pengembangan ilmu pragmatik, khususnya pragmatik dalam perspektif kultur spesifik.
\end{abstract}

Kata-kata Kunci: ketriaditisan makna, ketidaksantunan berbahasa, pragmatik kultur spesifik

\begin{abstract}
The objective of this research was to describe the types of triadicities of pragmatic contexts on impolite utterances in the Indonesian language in culture-specific perspective. The research data were the natural utterances in a culture-specific domain intrinsically containing triadicity of pragmatic contexts. The data were collected and presented through the observation methods, both through the engaged conversation technique and uninvolved conversation technique. The data gathering techniques being applied in the observation method were the recording and note-taking techniques. In addition to the conversation technique, an interview technique was applied both the face-to-face and indirect conversations. The data gathering stage was completed when the data was ready to be analyzed. Data analysis was carried out using the identity method, especially the extralingual identity method. This aligned with the contextual analysis in pragmatics in which contextual aspects must be identified. The results of the study showedthat there were 10 types of triadicities of pragmatic contexts on impolite utterances in the Indonesian language in culturespecific perspective. They were triadicities of pragmatic contexts in: (1) pretense, (2) association, (3) taboos, (4) taunting, (5) arrogance, (6) pleonasm, (7) puns, (8) insults, (9) teasing, (10) interjection. The findings of research bring the significant contribution to the development of pragmatics, particularly the culture-specific pragmatics.
\end{abstract}

Keywords: triadicity of meanings, linguistic impoliteness, culture-specific pragmatics

How to Cite: Rahardi, R. Kunjana.. (2020). Ketriaditisan Konteks Pragmatik Tuturan Tidak Santun: Perspektif Kultur Spesifik. Ranah: Jurnal Kajian Bahasa, 9(1), 106-128. doi: https:// doi.org/10.26499/rnh/v9i1.2340 


\section{INTRODUCTION}

The notion of triadicity and diadicity of meaning have not been widely discussed among linguists (Yu, 2011; Chen, 2017). In general, the notion of triadicity is understood as being interwoven with three other dimensions of meanings in pragmatics. The three dimensions include (1) speaker-hearer, (2) utterance meaning, and (3) context of utterance. Thus, understanding the utterances pragmatically cannot be separated from the three aforementioned dimensions (Bibok, 2001). In contrast, the diadicity of meaning considers only two dimensions of meanings, namely (1) the linguistic manifestation of the utterance, and (2) the meaning of the utterance (R. K. Rahardi, 2010).

Pragmatics is closely related to the former, i.e. the tradicity of meaning (Pagin, 2014). The phenomenon of linguistic impoliteness is no longer considered as a new pragmatic phenomenon (Timothy \& Janschewitz, 2008; Limberg, 2009). When the pragmatic research on linguistic politeness was widely done in the 1990s, linguists did not regard impoliteness as a new pragmatic phenomenon more than the fact that it was the opposite extreme of linguistic politeness in the politeness continuum proposed by linguist Geoffrey N. Leech (Triki, 2002; R. K. Rahardi, 2016).

The scale 'benefit and loss' as a parameter to measure whether an utterance is considered polite or impolite denotes that the utterance that causes more 'loss' in the part of the hearer can be categorized as an impolite utterance (Leech, 2007). However, the principles of impoliteness proposed by Bousfield, Locher, and Terkourafi are not the same as the concepts of impoliteness described by Leech (Limberg, 2009; Izadi, 2016). In the perspective proposed by Bousfiled et al., linguistic impoliteness includes the following acts: (1) mock impoliteness, (2) face-playing, (3) face-aggravating, (4) face-loss, and (5) face-threatening (Limberg, 2009).

The linguistic impoliteness as seen in the mock impoliteness is signaled with playful gratuitous attitude and action towards others. In addition to gratuitous action and behavior, mock impoliteness is considered impolite when it is characterized with playful jokes and jests. The tendency to twist any words into puns and word play in their speech is the manifestation of linguistic impoliteness (Sorlin, 2017; Rahardi, 2017a).

Face-playing categorized in linguistic impoliteness happens when the hearer feels upset whileconversing with the speaker. The speaker plays with the hearer's feeling and this game is done deliberately. Further, face-aggravating is one of the forms of linguistic 
impoliteness characterized by the hearer's upset feeling caused by the speaker's speech (Rahardi, 2017b; Sorlin, 2017).

The other characteristics of face-aggravating acts are the elements of cynical tones, insinuations, and insults which causeannoyance in the part of the hearer. Then, face threatening acts refer to the attitudes and behaviors that threaten faces. It is characterized with being forced to accept something as a fait accompli, not given any choice, making the hearer feels threatened.

Other face-threatening attitudes and behaviors are the elements of threats, coercion, fait accompli, and backstabbing. Further, the face-losing attitudes and behaviors include those that cause the hearer's feeling utterly humiliated and shamed in front of other people (Kampf, 2008; Limberg, 2009). The other characteristics of this type of linguistic impoliteness are elements of anger, harsh treatment, rudeness, insults, insinuation, and humiliating mockery. These negative treatments hurt the hearer's feeling and break his/her heart.

The objective of this research was to describe the types of triadicities of pragmatic contexts on impolite utterances in the Indonesian language in culture-specific perspective. In brief, the object of the research is the triadicity of pragmatic meaning of impoliteness in the Indonesian language. The perspective used in this research is the culture-specific pragmatics (Nureddeen, 2008; Mills, 2009).

The research will bring benefits to the development of pragmatic theories. The fastgrowing development of speech contexts demands faster development of research on pragmatic phenomena. Only through this will pragmatics, both the general pragmatics and culture-specific pragmatics, develop optimally (Rashid, Ismail, Ismail, \& Mamat, 2017).

\section{RESEARCH METHOD}

Research on triadicity of pragmatic context on impolite unnterances is a descriptive qualitative research. Pragmatics is the youngest and newest branch in linguistics. Thus, the research methodology applied in linguistic science and other linguistic branches do not automatically apply to the pragmatic research (Rahardi, 2019; Richards \& Rodgers, 2006). The object of this research is the triadicity of the pragmatic meanings of impoliteness found in the Indonesian language. Therefore, the research data include natural utterances containing triadicity of meaning of impoliteness in the Indonesian language. 
The research takes the perspective of culture-specific pragmatics (Goddard, 2009). The ready-made data in this research is the triadicity of meaning of linguistic impoliteness in a specific given language, i.e. Javanese. The Javanese culture was chosen because the researcher's lingual intuition is Javanese, making it easier to interpret and validate data collected from the research. The data are collected and presented using the observation method, both the involved conversation and uninvolved conversation techniques (Sudaryanto, 2016; Mahsun, 2005). The data gathering techniques applied in the observation method were recording and note-taking. In addition to the concersation technique, the interview technique was also applied, both face-to-face and indirect interviews.

The data collection was completed when each type of the research data was ready to be analyzed. The types of data were classified, after being selected and identified first. Therefore, the process of collecting data on triadicity has gone through systematic stages, starting from data identification, data selection, data classification, and data typification. After the data is presented systematically, the next methodological phase was to analyze the data (R. K. Rahardi, 2018; Sudaryanto, 2015).

The data analysis was carried out by implementing the identity analysis method. In the identity analysis method, the process of comparing and contrasting data with their external contexts takes place. In other words, the analysis method applied in this research was the contextual analysis method. The language external contexts are the main instruments in the comparing-contrasting actions in this research. The further analysis results were triangulated by the language experts to guarantee the validity and reliability of the analysis results. Hence, the research results on the triadicity of the pragmatic meaning of language impoliteness are scientifically accountable.

\section{DISCUSSION}

\section{Results}

The research that has been carried out resulted in the types of triadicities of pragmatic context as follows: (1) triadicity of pragmatic contexts in pretense, (2) triadicity of pragmatic contexts in association, (3) triadicity of pragmatic contexts in taboos, (4) triadicity of pragmatic contexts in taunting, (5) triadicity of pragmatic contexts in arrogance, (6) triadicity of pragmatic contexts in pleonasm, (7) triadicity of pragmatic contexts in puns, (8) triadicity of pragmatic contexts in insults, (9) triadicity of pragmatic 
contexts in teasing, (10) triadicity of pragmatic contexts in interjection. The ten manifestations of triadicities of pragmatic context are based on the data as seen in the following table.

Table 1

Manifestations of Triadicities of Pragmatic Context

\begin{tabular}{lc}
\multicolumn{1}{c}{ Triadicity of Pragmatic Contexts } & Utterances in Contexts \\
\hline $\begin{array}{l}\text { Triadicity of pragmatic contexts in } \\
\text { pretense. }\end{array}$ & X: Udah, nih? Nggak ada yang maju lagi? Ya udah selesai, yok! Kita \\
& pulang! \\
& Y: Ehh.. Buk, ya udah saya Buk.
\end{tabular}

$\mathrm{X}$ : Done? Does anyone else want to turn in their papers? Okay, then. Let's go home.

Y: Err.. ma'am. Yes, I have, ma'am..

Context of Utterance:

The utterance took place in the classroom of a university on 27 March 2013. The speaker was a 36- year-old female lecturer. The hearer was a 22-year-old female student. The speaker was waiting for her students to turn in the midterm test papers. However, some students did not have self-awareness and must be reminded and called out by the lecturer. The speaker felt that no more students would come forward to turn in their test papers.

Triadicity of pragmatic contexts in

X: Kamu punya pacar nggak, Mbak?

association.

$Y$ : Ya tergantung

X: Kalau 'tergantung' kenapa tidak diambil, Mbak? Kasihan pacarnya 'tergantung'.

$\mathrm{X}$ : Do you have a boyfriend, Miss?

Y: Well, it depends. (In Indonesian, the expression "it depends" translates literally as "It hangs")

$\mathrm{X}$ : If the boyfriend is hanging on the wall, why don't you take him down? I feel sorry that your boyfriend is hanging on the wall.

Context of Utterance

The conversation above took place in a seminar room of the university on 29 April 2013. The speaker was the 35-year-old female employee. The hearer was a 20-year-old female student. When the speaker was explaining public speaking, she asked the hearer whether she had a boyfriend or not. The hearer answered with "It depends or it hangs" which was considered strange by the speaker.

X: Mbak-Mbak, ini diwawancarai Mbak, ini Pak Kapolsek.

$Y$ : Asem kowe..

$\mathrm{X}$ : Ladies, Please interview this man. He is the Chief Police.

Y: Damn you...

Context of Utterance:

The utterance took place in front of the employee office in a school on 3 May 2013. The speaker was a 30-year-old male employee, and the hearer was a 28-year-old male employee. At that time, the speaker saw several female university students visiting the school to conduct a research. The students conducted an interview to collect data. The speaker asked the female students to interview the hearer.

X: Gemuk, Gemuk, Gendut, mau ke mana?

$Y:$ Kelas

$\mathrm{X}$ : Fatty, Fatty, Fatso, where are you going?

Y: Class

Context of Utterance:

The conversation took place beside the auditorium of a school on 3

May 2013. The speaker was a 13-year-old female student, while the 
Triadicity of pragmatic contexts in taboos.
Triadicity of pragmatic contexts in taunting.

Triadicity of pragmatic contexts in arrogance. hearer was a 13-year-old male student. The speaker bumped into the hearer near the auditorium and she called him names using the nicknames Fatty and Fatso.

X: Apa aksentuasi?

Y: Penekananaaaannn!!

$X:$ Bagian apa Mas yang suka ditekan?

$Y$ : (tersipu malu)

$\mathrm{X}$ : What is accentuation?

Y: Emphasissss!! (The word in Indonesian sounds like "pressure")

$\mathrm{X}$ : Which part of your body do you want to be pressed?

Y: (blushing)

Context of Utterance:

The utterance took place in the seminar room of a university on 29 April 2013. The speaker was a 35-year-old female employee. The hearer was a 22-year-old male student. The speaker asked the hearer the definition of accentuation. The hearer answered correctly that accentuation is emphasis. Then, the speaker gratuitously commented on the word.

$X$ : Tanganmu di kedua saku, ya?

$Y: Y a, B u k$

$X$ : Jangan beralih naruh di bagian yang lain ya!

Y: Ya ampun Buukk, aku gak gitu kale...

$\mathrm{X}$ : Do you put your hands in your pockets?

Y: Yes, ma'am.

$\mathrm{X}$ : Do not touch the other part (of your body), okay!

Y: Oh, my goodness, ma'am. I'm not that type of person.

Context of Utterance:

The Utterance took place in the seminar room of the university on 29 April 2013. The speaker was a 35-year-old female lecturer. The hearer was a 19-year-old male student. The speaker asked the hearer what he did when he was not confident in speaking in front of people. The hearer said that to reduce his nervousness, he would put his hands in his pockets.

$\mathrm{X}$ : Iki diapakke?

Y: Yo dicopy, mosok tok pangan?

$\mathrm{X}$ : What should we do with this?

Y: Of course to be copied. Were you thinking about eating it?

Context of Utterance:

The utterance took place in the library of a school on 2 May 2013. The speaker was a 13-year-old seventh-grade female student and the hearer was a 14-year-old male student. The speaker asked the hearer what they should do with the exercise distributed by their teacher.

$X$ : Kaти tu jajan-jajan dulu, daripada ke perpus ngapain!

$Y$ : Biasa pak, cari vitamin dengan $O L$.

X: You should hang out in the cafeteria more often, instead of going to the library all the time. What for?

Y: Well, the usual thing, Sir. Getting the vitamin through OL.

The context of utterance:

The utterance took place in the library of a school on May 2 2013. The speaker was a 13-year-old male seventh grade student, and the hearer was a 40-year-old male employee. The hearer asked the speaker to hang out in the cafeteria during the recess. The speaker preferred to go to the library to browse the Internet. 
Triadicity of pragmatic contexts in pleonasm.

Triadicity of pragmatic contexts in puns.

Triadicity of pragmatic contexts in insults.

Triadicity of pragmatic contexts in teasing.
X: Eh, daripada kamu jalannya lewat situ, mending terbang aja,deh.

$Y$ : Emang harus gitu, ya?

$\mathrm{X}$ : Er, rather than passing the street, it would be better if you fly.

Y: Okay, do I have to?

Context of Utterance:

The utterance took place in the schoolyard on May 2, 2013. The speaker was a 15-year-old eight grade female student. The hearer was a 14-year-old male student. The speaker addressed the hearer when he wanted to go into the classroom.

$\mathrm{X}$ : Koweki piye wiii??

Y: Piyek ki anak ayam!

$\mathrm{X}$ : What's wrong with you?

Y: Piyek is a chick.

Context of Utterance:

The utterance took place in front of a class of a school on May 2, 2013. The speaker was a 13-year-old female student. The hearer was a 14year-old female student. The speaker asked the hearer why she acted strange when the teacher asked her a question. The hearer answered playfully.

$\mathrm{X}$ : Jiwa seni, apa?

Y: Itu jiwa seni, Bu. Seni-seningan.

$\mathrm{X}$ : The artistic talent. What is it?

Y: It is an artistic talent, Ma'am. Seni-seningan.

Context of Utterance:

The utterance took place on April 18, 2013 at 10.40, in the noisy classroom, where students learned the Indonesian language. The speaker was a 35-year-old female teacher and the hearer was a 13-yearold student. The purpose of the utterance was to tease the hearer. The utterance was conveyed when the speaker asked the hearer why she chose the title of her composition as hotel. The hearer stated that the reason was art.

$\mathrm{X}$ : Ngopo, Pak? PDKT po?

Y: Wuaaa.. hayo biasane lan kudu ngono!

$\mathrm{X}$ : What are you doing? Are you making an approach on her?

Y: Well, that's what I do and what I must do!

Context of Utterance:

The utterance took place in front of the employee room in a school on May 3, 2013. The speaker was a 30-year-old male employee, and the hearer was a 45-year-old male employee. The speaker saw the hearer talking to a female guest from the university.

$X$ : Ini bentar lagi nikah.

Y: Weh, pak, nggak yo. Mosok lagi lulus SMP nikah

$\mathrm{X}$ : You must be getting married soon.

Y: What? No, sir. Of course not. I haven't even finished junior high school.

Context of Utterance:

The utterance took place in the employee room of a school on May 3, 2013. The speaker was a 45-year-old male employee and the hearer was a 16-year-old male student. The speaker was talking to the hearer during the recess. The speaker knew that the hearer would graduate from the junior high school. The speaker wanted to poke fun with the hearer. 
Triadicity of pragmatic contexts in interjection.
Y: Ini lihat ejaannya masih salah.

$X:$ Ya, ampun.

Y: Look. The speeling is incorrect.

$\mathrm{X}$ : Oh, my goodness!!

Context of Utterance:

The utterance took place on March 27, 2013, at 11.30 in a noisy class during the Indonesian for Foreign Speakers Course. The speaker was a 21-year-old female student, and the hearer was a 37-year-old male lecturer. The purpose of the utterance was to respond to the hearer's statement. The utterance was spoken when the speaker finished practicing teaching. The hearer commented on the speaker's not-sogood performance when she practiced teaching. The speaker expressed surprise when the hearer gave her feedback on her teaching.

$X$ : Inggit? Wow, merah, cedar!

$Y:$ iya, $B u$.

$\mathrm{X}$ : Inggit? Wow, red, cedar!

Y: Yes, Ma'am.

Context of Utterance:

The utterance took place on April 3, 2013 at 11.35 in the class during a relaxed BIPA (Indonesian for Foreign Learners) Course. The speaker was a 22-year-old lecturer and the hearer was a 22-year-old female student. The purpose of the utterance was the speaker's comment of the dress worn by the student. The utterance was expressed as the speaker appraised the hearer's physical appearance. The hearer wore a red dress which matched with her fair skin.

\section{Discussion}

Language impoliteness understood as mock impoliteness was first proposed by Bousfield (R. Rahardi, 2017; Limberg, 2009). Mock impoliteness in his view refers to playful and gratuitous behaviors. In addition to the lack of seriousness, an impolite gratuitous behavior is characterized with humorous small talks and jokes. The linguistic markers of the linguistic impoliteness are gratuitous behaviors characterized suprasegmentally by a tone of voice, word stress, duration, and intonation (Page, 2014; Zienkowski, 2014).

The pragmatic markers of the linguistic impoliteness include the situation of the utterances, the atmosphere of the utterance, the purpose of the utterance, the channel of the utterance, the participants, and other pragmatic contextual aspects. The following utterances excerpted from the authentic conversations can be categorized as the manifestations of impolite intentionally gratuitous act (Limberg, 2009; Kashiha \& Heng, 2014). The triadicity of pragmatic impoliteness in the Indonesian language below is based on a culture-specific dimension. 


\section{Triadicity of Pragmatic Contexts in Pretense}

Pretense is understood as a fake behavior or acting. The subcategory of gratuitous impoliteness manifested in pretense refers to the humorous and joking language behaviors in which the speaker does not mean what she or he says (Chen, 2017). What the speaker says is actually the opposite of what is expected by the hearer, as seen in the following excerpt.

Excerpt of Utterance 1:

X: Udah, nih? Nggak ada yang maju lagi? Ya udah selesai, yok! Kita pulang!

Y: Ehh.. Buk, ya udah saya Buk.

$\mathrm{X}$ : Done? Does anyone else want to turn in their papers? Okay, then. Let's go home.

Y: Err.. ma'am. Yes, I have, ma'am..

Context of Utterance:

The utterance took place in the classroom of a university on 27 March 2013. The speaker was a 36- yearold female lecturer. The hearer was a 22-year-old female student. The speaker was waiting for her students to turn in the midterm test papers. However, some students did not have self-awareness and must be reminded and called out by the lecturer. The speaker felt that no more students would come forward to turn in their test papers.

The impolite utterance spoken by the lecturer to the student was categorized as mock impoliteness because it contained the joking intention. The joke was seen in the utterance "Okay then. Let's go home!" The words "done" and "let's go home" in the utterance are not real invitation to go home. Such utterance is called an imperative with the pragmatic meaning to be sarcastic (R. K. Rahardi, 2019a; Kashiha \& Heng, 2014). Therefore, the imperative form with the sarcastic intention contains the elements of joking and humor, which is categorized in the mock impoliteness in the context of linguistic impoliteness.

In addition to the humor and joking dimensions as seen previously, the utterance also contains the dimension of seriousness. The dimension of seriousness tends to be an expression of irritation. This is evident in the words "Done? Does anyone else want to turn in their papers?" which were expressed in a rising intonation and high-pitched voice. A rising intonation and high-pitched tone of voice used in the utterance can signify the speaker's exasperation. A falling intonation in the utterance "Okay, then. Let's go home!" contains the intention of pretense. In the utterance, it is clear that the forms "Done?" and "Does anyone else want to turn in their papers?" contain impoliteness in speech event because it contains the pragmatic meaning or intention of pretense. The two questions in one utterance can be interpreted as an affirmation. 


\section{Triadicity of Pragmatic Contexts in Association}

Association is a correlation of ideas, memory, and sensory activities. The relevant ideas can be things or objects. Mock impoliteness manifested in association is understood as a linguistic behavior containing playful association of ideas with other things, objects and events. For example, associating someone with a certain figure, or words with a certain object, tends to contain the dimension of humor and jokes (Bucholtz \& Hall, 2007; Kashiha \& Heng, 2014). Therefore, the intentionally gratuitous act with association is characterized with linguistic behaviors showing humor or jokes as a result of associating things or objects having certain characteristics, such as physical characters, the name of job titles, and certain characteristics. The following example clarifies the subcategory of gratuitous impoliteness manifested in the association with jokes (Norrick, 2003; AduAmankwah \& McDowell, 2003).

Excerpt of Utterance 2:

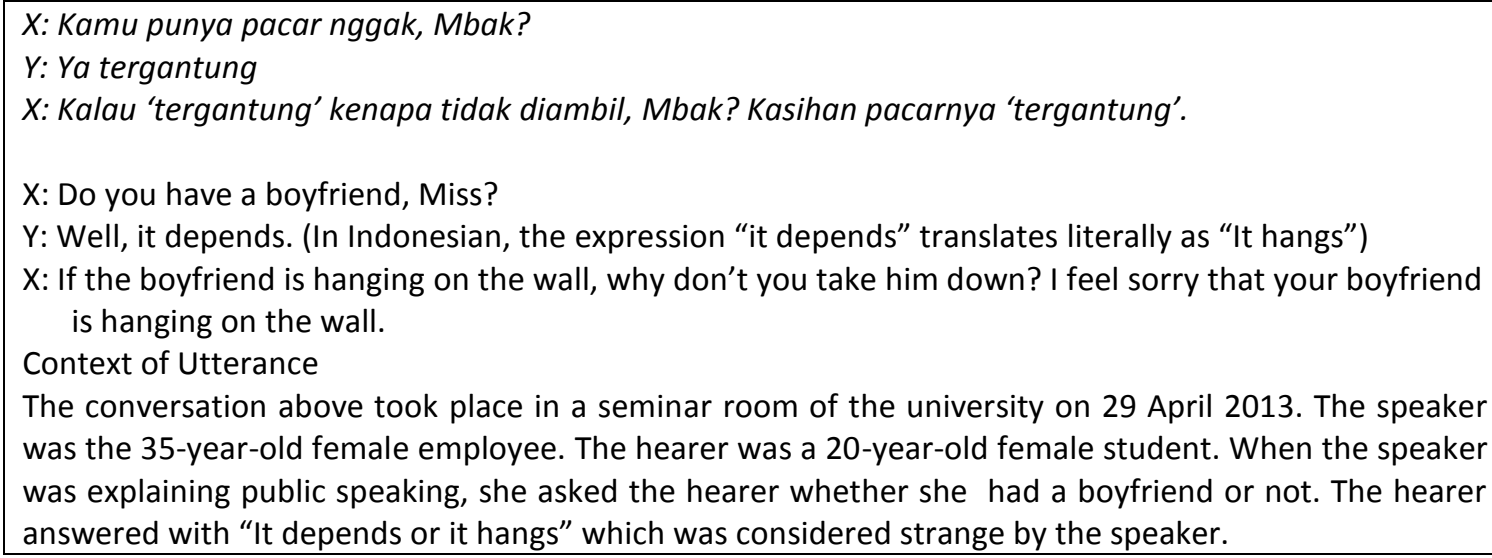

The excerpt of the utterance contains the dimension of linguistic impoliteness, especially that which is related to the gratuitous intention. The intentionally gratuitous act lies in the hearer's answer which said "It depends/It hangs", when the speaker asked her seriously whether or not she had a boyfriend. The intentionally gratuitous act was started with the speaker's question about the boyfriend which was considered impolite as she asked a personal question, as in "Do you have a boyfriend, Miss?". The question might intrude the hearer's personal space. Because of the gratuitous question, the hearer was offended, which prompted her to answer in a gratuitous manner. The gratuitous answer was "It depends/It hangs".

Naturally, the speaker frowned at the hearer's answer, which created another string of impolite utterances, as in "If the boyfriend is hanging on the wall, why don't you take him down?", and further commented by the speaker with "I feel sorry that your boyfriend 
is hanging on the wall." From the linguistic dimension, the speaker's gratuitous utterance was spoken in a rising intonation and a moderate tone. In contrast, the hearer's answer was expressed in a flat intonation and a high tone (Darling \& Steinberg, 1993; House, 2006). Another utterance containing the gratuitous impoliteness dimension can be seen in the following example.

Excerpt of Utterance 3:

X: Mbak-Mbak, ini diwawancarai Mbak, ini Pak Kapolsek.
Y: Asem kowe..
X: Ladies, Please interview this man. He is the Chief Police.
Y: Damn you...
Context of Utterance:
The utterance took place in front of the employee office in a school on 3 May 2013. The speaker was a
30 -year-old male employee, and the hearer was a 28 -year-old male employee. At that time, the
speaker saw several female university students visiting the school to conduct a research. The students
conducted an interview to collect data. The speaker asked the female students to interview the
hearer.

The intentionally gratuitous act was seen in the vocative "Pak Kapolsek" or The Chief Police to refer to the male employee whose physical appearance could be associated with a chief police. The expression "chief police" to refer to a fellow employee was intended as a joke. Thus, it can be said that humor and joke can be represented by an association with a certain figure. In the context of impoliteness, the reference using the association model to incite humor can be categorized as impoliteness because of the implied intentionally gratuitous act (Sorlin, 2017). The utterance "Damn you!" expressed by the hearer also contained impoliteness because it was a form of swearword gratuitously expressed to respond to the previous gratuitous utterance. This is an example of intentionally gratuitous act using another physical association.

Excerpt of Utterance 4:

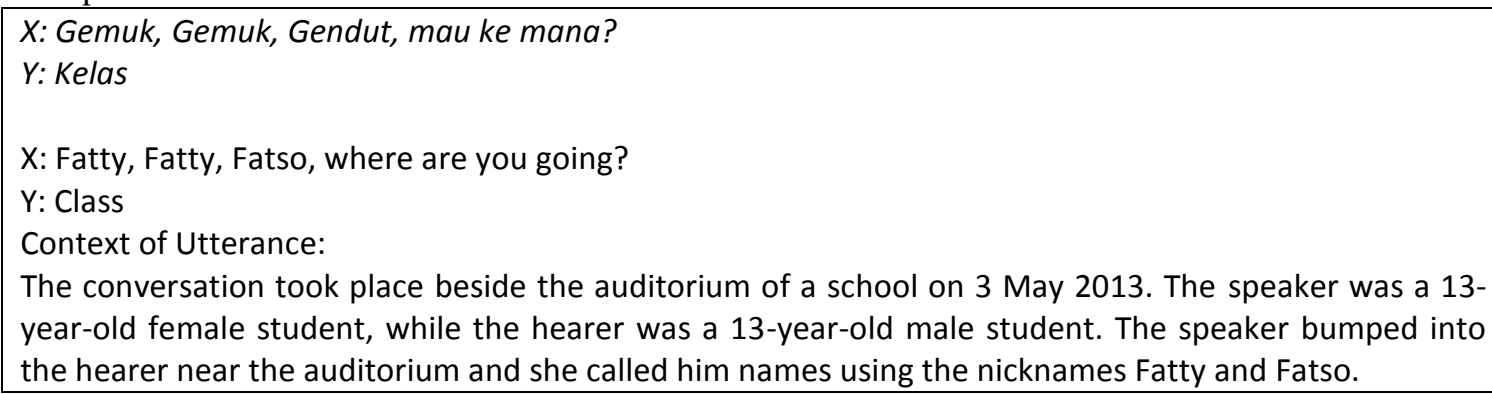

The utterance "Fatty, Fatty, Fatso, where are you going?" spoken by the female student to another student in the above excerpt contained impoliteness. The category of impoliteness was intentionally gratuitous act using the physical association. Among peers, children use nicknames which are associated with physical appearance. For example, a fat 
student is nicknamed "Fatty" or "Fatso". A lanky and skinny student is also usually given nicknames which associate him with his lankiness. In the language impoliteness study, the use of such language forms is categorized as impoliteness (Timothy \& Janschewitz, 2008). Linguistically, the utterance above was expressed in a high note, by stressing the words and shouting it out loud. The description of the suprasegmental aspects in linguistics is intended to emphasize the gratuitous intention using physical association as shown in the utterance above (Fraser, 1999).

\section{Triadicity of Pragmatic Contexts in Taboos}

Taboos refer to something which cannot be touched, spoken, etc. because it is related to the dangerous supersitions, abstinence, and prohibition (Fleming, 2015; Timothy \& Janschewitz, 2008). The association of taboos is interwoven in the ideas, memory, or sensory activities associated with prohibited actions because they are impolite to be spoken. Therefore, the impolite gratuitous utterance associated with taboos is characterized with linguistic behaviors containing humor or jokes by associating them with taboo things or objects which are prohibited to be spoken.

Excerpt of Utterance 5:

X: Apa aksentuasi?
Y: Penekananaaaannn!!
X: Bagian apa Mas yang suka ditekan?
Y: (tersipu malu)
X: What is accentuation?
Y: Emphasissss!! (The word in Indonesian sounds like "pressure")
X: Which part of your body do you want to be pressed?
Y: (blushing)
Context of Utterance:
The utterance took place in the seminar room of a university on 29 April 2013. The speaker was a 35-
year-old female employee. The hearer was a 22-year-old male student. The speaker asked the hearer
the definition of accentuation. The hearer answered correctly that accentuation is emphasis. Then, the
speaker gratuitously commented on the word.

The excerpt of utterance above has an impolite intention in the language practice. The purpose of the language impoliteness was expressed in the intentionally gratuitous act which is evident in the utterance "Which part of the body do you want to be pressed?" This gratuitous utterance caused the hearer to blush and lose for words to respond. At a glance, the utterance was intended as a humor (Zienkowski, 2014). However, it caused an embarrassment in the part of the student. Therefore, it can be said thet the impolite utterance manifested in the gratuitous utterance above caused the student to feel 
embarrassed. Another example of intentionally gratuitous act in association using taboo words can be seen in the following excerpt.

Excerpt of Utterance 6:

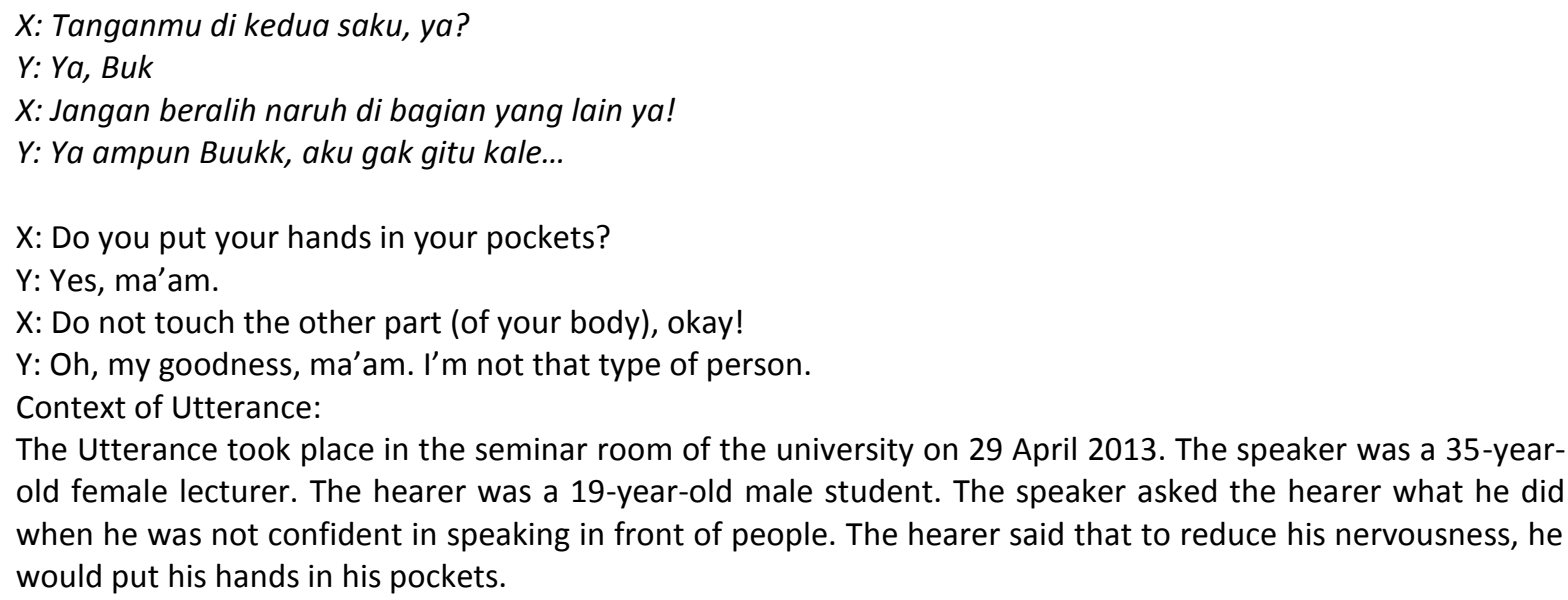

The dimension of humor and jokes in the utterance is "Do not touch the other part (of your body), okay!" The punchline of this joke lies in the speaker's prohibition not to touch the other part (of the body) when he put his hands inside his pockets. The meaning implied in the statement is that the student will touch his private part (genital). At a glance, the utterance is intended to be funny. On a closer look, the utterance contains an impolite intention (Timothy \& Janschewitz, 2008), especially because the statement was spoken by a female teacher to the male student.

The impolite intention in the excerpt above is seen in the association with the taboo expressions, especially in the utterance "touch the other part (of your body)" which is associated with the male genital. Linguistically, the utterance was spoken in a falling intonation because it is a prohibition. The tone of voice to express the intention was a high note. The use of suprasegmental aspect to convey the intention of intentionally gratuitous act is quite convincing, but actually it is not.

\section{Triadicity of Pragmatic Contexts in Taunting}

Cynicism is an attitude or act to taunt someone in a condescending manner; an inclination to believe that people are motivated purely by self-interest; skepticism. The impolite speech categorized in a gratuitous behavior seen in cynicism can be understood as a linguistic behavior containing insincerity, jokes, or condescending humor addressed to the hearer. The next utterance is identified as the subcategoty of intentionally gratuitous act in the form of cynical taunting (Van Eck, 2006).

Excerpt of Utterance 7: 
X: Iki diapakke?

Y: Yo dicopy, mosok tok pangan?

$X:$ What should we do with this?

$Y$ : Of course to be copied. Were you thinking about eating it?

Context of Utterance:

The utterance took place in the library of a school on 2 May 2013. The speaker was a 13-year-old seventh-grade female student and the hearer was a 14-year-old male student. The speaker asked the hearer what they should do with the exercise distributed by their teacher.

From the impoliteness point of view, the utterance "Of course to be copied. Were you thinking about eating it?" contains a gratuitous behavior. Although the utterance was spoken among friends, the gratuitous aspect was evident in the utterance. Normally, an exercise paper is not eaten, but copied. Therefore, there lies the subcategory of the gratuitous dimension, namely cynicism with taunting. In a community social life, a gratuitous behavior is often delivered through cynical taunting (R. K. Rahardi, Setyaningsih, \& Dewi, 2014).

Thus, it can be said that the manifestation of linguistic impoliteness does not happen only in the education domain as seen in the previous excerpt, but it also happens in other domains. Linguistically, the bantering among friends is delivered in a high note and a rising intonation. The use of suprasegmental aspects shows that the utterance was delivered enthusiastically. The Javanese diction in the utterance, which is the first language of both the speaker and the hearer, shows that the utterance was highly charged with emotion.

\section{Triadicity of Pragmatic Contexts in Arrogance}

Arrogance is defined as an attitude of superiority manifested in an overbearing manner or in presumptuous claims or assumptions. Arrogance refers to the quality of behaving as if one were more important than other people. In the context of communication, being pompous is categorized as being impolite. Thus, the gratuitous arrogance is a linguistic behavior where the speaker delivers humor or joke exaggerating one's own strength to the hearer (Adu-Amankwah \& McDowell, 2003). Typically, the gratuitous utterance of this type is delivered in a pompous manner, as seen in the following excerpt. 
Excerpt of Utterance 8:

X: Kamu tu jajan-jajan dulu, daripada ke perpus ngapain!
Y: Biasa pak, cari vitamin dengan OL.
X: You should hang out in the cafeteria more often, instead of going to the library all the time. What
for?
Y: Well, the usual thing, Sir. Getting the vitamin through OL.
The context of utterance:
The utterance took place in the library of a school on May 2 2013. The speaker was a 13 -year-old male
seventh grade student, and the hearer was a 40 -year-old male employee. The hearer asked the
speaker to hang out in the cafeteria during the recess. The speaker preferred to go to the library to
browse the Internet.

The gratuitous aspect delivered by the student to the male employee was seen in the choice of diction "vitamin and OL". Vitamin is usually extracted from food, but gratuitously the student mentioned that he wanted to get the vitamin through online browsing. The diction "OL" was a further evidence of his intentionally gratuitous act as there was a chance that the employee did not know the meaning of OL, which refers to being online or browsing the Internet.

From the tone of voice and intonation, the utterance was delivered in a high note and rising intonation indicating enthusiasm. It means that the gratuitous attitude was conveyed in full confidence (Hewitt, 2014). From the pragmatic dimension, the utterance spoken by the student to the employee contained elements of an intentionally gratuitous act. The age of the speaker and hearer can indicate the intentionally gratuitous act. Pragmatically, the purpose of the utterance which was not explicitly stated to the employee also shows that the young boy behaved frivolously to the employee.

\section{Triadicity of Pragmatic Contexts in Pleonasm}

Pleonasm refers to the use of more words than are necessary to convey meaning, either as a fault of style or for emphasis. For example, the sentence "We must and are obliged to respect each other." This sentence contains pleonasm, as the words "must" and "are obliged to" are used redundantly. In communication, the speaker who exaggerates what she or he is talking about, or speaks highly of oneself, is considered impolite. The intentionally gratuitous act using pleonasm is characterized with linguistic behaviors containing humor or jokes using exaggeration, as seen in the following utterance (Norrick, 2003). 
Excerpt of Utterance 9:

$X:$ Eh, daripada kamu jalannya lewat situ, mending terbang aja, deh.

$Y$ : Emang harus gitu, ya?

$X:$ Er, rather than passing the street, it would be better if you fly.

Y: Okay, do I have to?

Context of Utterance:

The utterance took place in the schoolyard on May 2, 2013. The speaker was a 15-year-old eight grade female student. The hearer was a 14-year-old male student. The speaker addressed the hearer when he wanted to go into the classroom.

The impoliteness aspect of the utterance above lies in the diction 'It would be better if you fly." The manifestation of impoliteness is the intentionally gratuitous act between a male and a female student when they went into the classroom. It would be strange and funny to fly into the classroom. So, the punchline of the utterance lies in the humorous intention of the speaker's utterance to the hearer. At a glance, the utterance was intended to poke fun or to be funny. Actually, however, the utterance is categorized as being impolite (Adu-Amankwah \& McDowell, 2003). Linguistically and suprasegmentally, the utterance was conveyed in a high note and a rising intonation. The linguistic markers affirm that the pragmatic meaning of the utterance being delivered was categorized as pleonasm using humor.

\section{Triadicity of Pragmatic Contexts in Puns}

Pun is a joke exploiting the different possible meanings of a word or the fact that there are words which sound alike but have different meanings. Puns, to a certain degree, can be fun because they contain humorous elements. However, when they are used excessively, they may provoke annoyance. For example, the word piye (How's that?) is being twisted into piyek (a chick), as seen in the following excerpt.

Excerpt of Utterance 10:

X: Koweki piye wiii??
Y: Piyek ki anak ayam!
X: What's wrong with you?
Y: Piyek is a chick!
Context of Utterance:
The utterance took place in front of a class of a school on May 2, 2013. The speaker was a 13-year-old
female student. The hearer was a 14-year-old female student. The speaker asked the hearer why she
acted strange when the teacher asked her a question. The hearer answered playfully.


The pun piyek to refer to the chick is twisted from the Javanese word piye, which means "What's wrong with you?" has a gratuitous pragmatic meaning as it contains humor or joke. Even though the linguistic behavior has a low degree of intentionally gratuitous act, in the context of language impoliteness, the behavior can be categorized as impolite (Goddard, 2012). The intentionally gratuitous act subcategory of puns expressed through jokes is ubiquitous in the religious domain. A religious figure often uses puns to attract people's attention during a sermon to make it easier for them to accept and understand the sermon.

In the family domain, puns often appear in the relaxed situation. It aims to create a bond between the family members. Linguistically, the utterance uses a high note and a falling intonation. The suprasegmental aspect of the utterance emphasized that the gratuitous intention was found in the utterance. The use of the Javanese word to respond to the speaker shows that the intentionally gratuitous act of the utterance was very evident. The other example of the use of humorous-nuanced puns can be seen in the following excerpt.

Excerpt of Utterance 11:

X: Jiwa seni, apa?
Y: Itu jiwa seni, Bu. Seni-seningan.
X: The artistic talent. What is it?
Y: It is an artistic talent, Ma'am. Seni-seningan.
Context of Utterance:
The utterance took place on April 18, 2013 at 10.40, in the noisy classroom, where students learned
the Indonesian language. The speaker was a 35 -year-old female teacher and the hearer was a 13 -year-
old student. The purpose of the utterance was to tease the hearer. The utterance was conveyed when
the speaker asked the hearer why she chose the title of her composition as hotel. The hearer stated
that the reason was art.

The intentionally gratuitous act of the pun subcategory lies in the form "It is an artistic talent, Ma'am. Seni-seningan.” The utterance was expressed by twisting the form "seni (art)" into "seni-seningan". The purpose was to poke fun through the sound symbolism. However, the joke tended to disrespect the speaker who expected to receive a serious response. The speaker was upset because the hearer did not answer seriously. Instead, she answered playfully by making puns. 


\section{Triadicity of Pragmatic Contexts in Insults}

Insult refers to a disrespectful act or abusive remark intended to degrade someone or condescend other people. The gratuitous and condescending act addressed to another person is categorized as being impolite. The intentionally gratuitous act becomes obvious when the person insults other people although the insults were conveyed jokingly or playfully (Norrick, 2003). The example of such utterance can be seen clearly in the following excerpt.

Excerpt of Utterance 12:

X: Ngopo, Pak? PDKT po?

Y: Wuaaa.. hayo biasane lan kudu ngono!

$\mathrm{X}$ : What are you doing? Are you making an approach on her?

Y: Well, that's what I do and what I must do!

Context of Utterance:

The utterance took place in front of the employee room in a school on May 3, 2013. The speaker was a 30 -year-old male employee, and the hearer was a 45-year-old male employee. The speaker saw the hearer talking to a female guest from the university.

In the excerpt above, both the speaker and the hearer used the form of intentionally gratuitous act in the conversation. It means that both interlocutors expressed their impolite intention in the conversation. The utterance "What are you doing? Are you making an approach on her?" contains the humorous intention because it was intended to tease the hearer. Such an utterance in the impoliteness study is categorized as impolite because the person being teased was much older (Locher, 2013). Using such an utterance to older people was not recommended, especially when the utterance was expressed in the ngoko Javanese (the lowest form of Javanese commonly used among peers and subordinates).

Such an utterance will make the person being spoken to feel degraded, even though it was expressed playfully. Thus, the utterance spoken by the hearer to respond to the impolite statement was "Well, that's what I do and what I must do!", which was equally impolite, but was natural given the way the speaker addressed him. Linguistically, the gratuitous utterance manifested in the Javanese language emphasized the frivolous intent.

\section{Triadicity of Pragmatic Contexts in Teasing}

Teasing can be understood as making fun of or attempting to provoke someone in a playful way. In the context of language impoliteness, the meaning of the word refers to provoking or picking on someone. Thus, the gratuitous behavior commonly done with joke or humor tends to aggravate someone's feelings, self-esteem, and dignity (Habib, 2008; 
Hay, 2000). In other words, someone's comfort is being intruded. In this regard, the following utterance can be observed.

Excerpt of Utterance 13:

$\mathrm{X}$ : Ini bentar lagi nikah.

Y: Weh, pak, nggak yo. Mosok lagi lulus SMP nikah

$X$ : You must be getting married soon.

Y: What? No, sir. Of course not. I haven't even finished junior high school.

Context of Utterance:

The utterance took place in the employee room of a school on May 3, 2013. The speaker was a 45year-old male employee and the hearer was a 16 -year-old male student. The speaker was talking to the hearer during the recess. The speaker knew that the hearer would graduate from the junior high school. The speaker wanted to poke fun with the hearer.

In the excerpt above, the utterance "You must be getting married soon" is categorized as a gratuitous behavior with the pragmatic meaning of teasing. Specifically, the utterance shows the subcategory of teasing. The teasing lies in the statement about "marriage" stated by the employee to the junior high school student who was still 16 years old. Such utterance flaunts the maxims of communication in Grice's Principles of Cooperation (1984) because normally a 16-year-old student is not allowed to get married yet. Linguistically, the utterance was expressed in a high note and the word "married" was emphasized.

The use of suprasegmental aspects such as intonation, tone of voice, and word stress in expressing a linguistic form will determine the meaning of the utterance. In addition, the choice of a wrong diction in the conversation involving an underage student also determines whether the utterance was polite or impolite (Sorlin, 2017). This does not only happen in the education domain as seen in the above excerpt. This also happens in other domains, such as in family and religious domains.

\section{Triadicity of Pragmatic Contexts Interjection}

Interjection can be undersood as request, suggestion, or warning. In linguistic impoliteness, interjection appears in the exclamative forms, such as "wow", "Oh, my Goodness!!”, “ah", and "Ouch!" However, the exclamative forms were expressed through humor and jokes, as seen in the following excerpt. 
Excerpt of Utterance 14:

Y: Ini lihat ejaannya masih salah.

$\mathrm{X}$ : Ya, ampun.

Y: Look. The speeling is incorrect.

$\mathrm{X}$ : Oh, my goodness!!

Context of Utterance:

The utterance took place on March 27, 2013, at 11.30 in a noisy class during the Indonesian for Foreign Speakers Course. The speaker was a 21-year-old female student, and the hearer was a 37-year-old male lecturer. The purpose of the utterance was to respond to the hearer's statement. The utterance was spoken when the speaker finished practicing teaching. The hearer commented on the speaker's not-sogood performance when she practiced teaching. The speaker expressed surprise when the hearer gave her feedback on her teaching.

The utterance "Oh, My Goodness!” to respond to the hearer's previous utterance can be considered as the manifestation of impoliteness. In addition to the element of surprise, there was a hint of irritation detected in the linguistic form. Thus it can be said that the gratuitous forms containing surprise and irritation are categorized as impolite. The pragmatic meaning of the utterance shown in the explanatory forms nuanced with surprise and irritation as in the previous excerpt happen in the communicative exchanges among the society in the domains other than education (R. K. Rahardi et al., 2014).

The jokes expressed by the lecturer can turn into an impolite speech when the joke is not expressed properly in the right context. The pragmatic meaning of "poking fun" is clearer when the suprasegmental aspects are analyzed to see the gratuitous behavior more clearly. The utterance above was intended to clarify this statement. The other example of impoliteness in the subcategory of "poking fun" using humor can be seen in the following example.

Excerpt of Utterance 15:

$X:$ Inggit? Wow, merah, cedar!

Y: iya, Bu.

X: Inggit? Wow, red, cedar!

Y: Yes, Ma'am.

Context of Utterance:

The utterance took place on April 3, 2013 at 11.35 in the class during a relaxed BIPA (Indonesian for Foreign Learners) Course. The speaker was a 22-year-old lecturer and the hearer was a 22-year-old female student. The purpose of the utterance was the speaker's comment of the dress worn by the student. The utterance was expressed as the speaker appraised the hearer's physical appearance. The hearer wore a red dress which matched with her fair skin.

In the above utterance, the linguistic form "Inggit? Wow, red, cedar!" expressed by the lecturer to the student was not a mere joke or humor. However, because the expression was expressed in a joking manner, the statement might offend the student. The expression spoken to comment on the contrasting colors between the color of the dress and the 
student's inflexion is considered impolite. The intention to joke may change into impoliteness when the context was not right (Goddard, 2012). Instead of smiling from the compliment or laughing at the lecture's joke, the student might purse her lips and felt offended. The description of the linguistic aspects both segmentally and suprasegmentally can indicate the impolite intent, as seen in the above utterance.

\section{CLOSING}

The following conclusion and limitations can be said about the research. First, there are 10 types of triadicitiesof pragmatic contexts of impoliteness utterances in the Indonesian language based on the research data. They are: (1) triadicity of pragmatic contexts in pretense, (2) triadicity of pragmatic contexts in association, (3) triadicity of pragmatic contexts in taboos, (4) triadicity of pragmatic contexts in taunting, (5) triadicity of pragmatic contexts in arrogance, (6) triadicity of pragmatic contexts in pleonasm, (7) triadicity of pragmatic contexts in puns, (8) triadicity of pragmatic contexts in insults, (9) triadicity of pragmatic contexts in teasing, (10) triadicity of pragmatic contexts in interjection. The study has found several findings of triadicities of pragmatic contexts, but a limitation still occurred in the implementation of this research. The most prominent limitation is that the research still lacks of varieties of data found in the field. Therefore, other studies with the research data from other domains must be collected and analyzed to enrich the research data.

\section{BIBLIOGRAPHY}

Adu-Amankwah, D., \& McDowell, J. (2003). An ethnopragmatic study of jokes and joking in an Akan community. Folklore.

Bibok, E. N. T. \& K. (2001). Pragmatics and the Flexibility of Word Meaning (1st ed.). Amsterdam: Elsevier Science Ltd.

Bucholtz, M., \& Hall, K. (2007). Language and Identity. In A Companion to Linguistic Anthropology. https://doi.org/10.1002/9780470996522.ch16

Chen, J. (2017). Research Trends in Intercultural Pragmatics. Australian Journal of Linguistics. https://doi.org/10.1080/07268602.2016.1204903

Darling, N., \& Steinberg, L. (1993). Parenting Style as Context: An Integrative Model. Psychological Bulletin. https://doi.org/10.1037/0033-2909.113.3.487

Fleming, L. (2015). Taxonomy and Taboo: The (Meta)Pragmatic Sources of Semantic Abstraction in Avoidance Registers. Journal of Linguistic Anthropology. https://doi.org/10.1111/jola.12073

Fraser, B. (1999). What are discourse markers? Journal of Pragmatics. https://doi.org/10.1016/S0378-2166(98)00101-5 
Goddard, C. (2009). Not taking yourself too seriously in Australian English: Semantic explications, cultural scripts, corpus evidence. Intercultural Pragmatics. https://doi.org/10.1515/IPRG.2009.002

Goddard, C. (2012). "Early interactions" in Australian English, American English, and English English: Cultural differences and cultural scripts. Journal of Pragmatics. https://doi.org/10.1016/j.pragma.2012.04.010

Habib, R. (2008). Humor and disagreement: Identity construction and cross-cultural enrichment. Journal of Pragmatics. https://doi.org/10.1016/j.pragma.2008.02.005

Hay, J. (2000). Functions of humor in the conversations of men and women. Journal of Pragmatics. https://doi.org/10.1016/S0378-2166(99)00069-7

Hewitt, K. (2014). The regional context. In Advances in Asian Human-Environmental Research. https://doi.org/10.1007/978-94-007-6311-1_1

House, J. (2006). Constructing a context with intonation. Journal of Pragmatics. https://doi.org/10.1016/j.pragma.2005.07.005

Izadi, A. (2016). Over-politeness in Persian professional interactions. Journal of Pragmatics, 102. https://doi.org/10.1016/j.pragma.2016.06.004

Kampf, Z. (2008). The pragmatics of forgiveness: Judgments of apologies in the Israeli political arena. Discourse and Society. https://doi.org/10.1177/0957926508092244

Kashiha, H., \& Heng, C. S. (2014). Discourse functions of formulaic sequences in academic speech across two disciplines. GEMA Online Journal of Language Studies, 14(2), 15-27. https://doi.org/10.17576/GEMA-2014-1402-02

Leech, G. (2007). Politeness: Is there an East-West divide? Journal of Politeness Research. https://doi.org/10.1515/PR.2007.009

Limberg, H. (2009). Impoliteness and threat responses. Journal of Pragmatics. https://doi.org/10.1016/j.pragma.2009.02.003

Locher, M. A. (2013). Cyberpragmatics: Internet-Mediated Communication in Context. Journal of Pragmatics. https://doi.org/10.1016/j.pragma.2012.12.002

Mahsun, M. (2005). Metode Penelitian Bahasa. Jakarta: PT Raja Grafindo Persada. https://doi.org/10.1200/JCO.2008.17.1991

Mills, S. (2009). Impoliteness in a cultural context. Journal of Pragmatics. https://doi.org/10.1016/j.pragma.2008.10.014

Norrick, N. R. (2003). Issues in conversational joking. Journal of Pragmatics. https://doi.org/10.1016/S0378-2166(02)00180-7

Nureddeen, F. A. (2008). Cross cultural pragmatics: Apology strategies in Sudanese Arabic. Journal of Pragmatics. https://doi.org/10.1016/j.pragma.2007.11.001

Page, R. (2014). Saying "sorry": Corporate apologies posted on Twitter. Journal of Pragmatics. https://doi.org/10.1016/j.pragma.2013.12.003

Pagin, P. (2014). Critical Pragmatics. Philosophical Review. https://doi.org/10.1215/00318108-2683585

Rahardi, R. (2017). Pragmatic phenomena constellation in specific culture dimension language study. International Journal of Humanity Studies. https://doi.org/10.24071/ijhs.2017.010109

Rahardi, R. K. (2010). Sosiopragmatik (1st ed.). Jakarta: Erlangga.

Rahardi, R. K. (2016). Personal and Communal Assumptions to Determine Pragmatic Meanings of Phatic Functions. Lingua Cultura, 10(10(2)), 95-98. https://doi.org/10.21512/lc.v10i2.897

Rahardi, R. K. (2017a). Linguistic Impoliteness in The Sociopragmatic Perspective. Jurnal Humaniora. https://doi.org/10.22146/jh.v29i3.24954

Rahardi, R. K. (2017b). Pragmatic Phenomena Constellation in Specific Culture 
Dimension Language Study. International Journal of Humanity Studies, 1(1), 84-92. https://doi.org/10.24071/ijhs.2017.010109

Rahardi, R. K. (2018). Elemen dan Fungsi Konteks Sosial, Sosietal, dan Situasional dalam Menentukan Makna Pragmatik Kefatisan Berbahasa. In Prosiding Seminar Tahunan Linguistik Universitas Pendidikan Indonesia (SETALI 2018) (pp. 654-658). Bandung: Sekolah Pascasarjana Universitas Pendidikan Bandung.

Rahardi, R. K. (2019a). Integrating social, societal, cultural, and situational contexts to develop pragmatics course learning materials: preliminary study integrasi sosial , sosial, budaya, dan konteks situasional untuk mengembangkan materi pembelajaran pragmatik: studi , 5(2), 169-178. https://doi.org/10.22202/jg.2019.v5i2.3572

Rahardi, R. K. (2019b). Pragmatic Perspective on Phatic Functions and Language Dignity. International Journal of Engineering and Advanced Technology, 8(5C, May 2019), 261-268. https://doi.org/10.35940/ijeat.E1039.0585C19

Rahardi, R. K., Setyaningsih, Y., \& Dewi, R. P. (2014). Kata fatis penanda ketidaksantunan pragmatik dalam ranah keluarga. Adabiyyāt: jurnal bahasa dan sastra. https://doi.org/10.14421/ajbs.2014.13201

Rashid, R. A., Ismail, I. R., Ismail, R., \& Mamat, R. (2017). Ketidaksantunan dalam Perbualan Bahasa Jepun oleh Pemandu Pelancong Malaysia. GEMA Online Journal of Language Studies, 17(3), 86-105. https://doi.org/10.17576/gema-2017-1703-06

Richards, J. C., \& Rodgers, T. (2006). Method: Approach, Design, and Procedure. TESOL Quarterly. https://doi.org/10.2307/3586789

Sorlin, S. (2017). The pragmatics of manipulation: Exploiting im/politeness theories. Journal of Pragmatics. https://doi.org/10.1016/j.pragma.2017.10.002

Sudaryanto. (2015). Metode dan Aneka Teknik Analisis Bahasa: Pengantar Penelitian Wahana Kebudayaan secara Linguistis (1st ed.). Yogyakarta: Sanata Dharma University Press.

Sudaryanto. (2016). Metode dan Aneka Teknik Analisis Bahasa (1st ed.). Yogyakarta: Sanata Dharma University Press.

Timothy, J., \& Janschewitz, K. (2008). The pragmatics of swearing. Journal of Politeness Research.

Triki, M. (2002). Pragmatics for ESP Purposes. GEMA Online Journal of Language Studies.

Van Eck, R. (2006). Digital Game-Based Learning: It's Not Just the Digital Natives Who Are Restless. EDUCAUSE Review. https://doi.org/10.1145/950566.950596

Yu, K. A. (2011). Culture-specific concepts of politeness: Indirectness and politeness in English, Hebrew, and Korean requests. Intercultural Pragmatics. https://doi.org/10.1515/iprg.2011.018

Zienkowski, J. (2014). Discursive pragmatics. https://doi.org/10.1075/hoph.8.01zie 